\title{
Biological Control of Coniella granati Saccardo in Pomegranate
}

\author{
Nasibe Tekiner* ${ }^{*}$ Recep Kotan, Elif Tozlu, Fatih Dadaşoğlu \\ Department of Plant Protection, Faculty of Agriculture, Atatürk University, Turkey
}

Received October 7, 2019; Revised November 26, 2019;Accepted December 4, 2019

Copyright $@ 2020$ by authors, all rights reserved. Authors agree that this article remains permanently open access under the terms of the Creative Commons Attribution License 4.0 International License

\begin{abstract}
Coniella granati Saccardo (Synonym Pilidiella granati) is a fungal pathogen that causes fruit brown rot, cankers on shoots and crown rot of pomegranate trees. Although cultural and chemical control is recommended against C. granati; cultural control is not enough and limited number of advisable fungicides used in chemical control against this pathogen. Therefore, alternative strategies are needed for this pathogen control. In this context, it was aimed to investigate the effect of some bacterial biocontrol agents against C. granati under in vitro conditions. Dual culture of eleven bacterial biocontrol agents [1 Bacillus megaterium (TV 3D), 3 Bacillus substilis (TV 6F, TV 17C, CP1), 1 Bacillus cereus (TV 85D), 1 Paenibacillus polymxa (TV 12E), 2 Pseudomonas fluorescens (MF 3, AR 9), 1 Burkholderia cepacia (BA 7) 1 Pantoea agglomerans (MF 1) and 1 Bacillus thuringiensis (BAB 420)] were tested for antagonistic properties against $C$. granati. Percent inhibition rate values changed from $11.90 \%$ to $66.67 \%$ in dual culture. B. cereus (TV 85D, $66.67 \%$ ) was the most effective strains against $C$. granati respectively by B. substilis (TV 17C, 64.29\%; TV 6F, $60.71 \%$ ) in in vitro. As a result, promising results were obtained from these isolates in in vitro conditions. These isolates should be tested in vivo conditions for controlling the post-harvest decay of pomegranate fruits caused by $C$. granati.
\end{abstract}

Keywords Biological Control, Bioagent Bacteria, Bacillus sp., Bacillus cereus, Coniella granati

\section{Introduction}

Pomegranate (Punica granatum L.) is one of the oldest tropical/subtropical fruit cultivated. In addition to its high nutritional value, it has gained more importance in recent years as it is an important source of antioxidants [1,2].
Pomegranate is a fruit produced in most countries in the world, because it can be grown in various climatic and soil conditions and stored for a long time [2]. However, many biotic and abiotic factors limit the production of this product. it is estimated that the annual loss rate due to biotic factors in plant production is $36.5 \%$ [3], and 1/3 of these losses are post-harvest losses [5].

Pomegranate fruit is susceptible to many fungal pathogens that cause pre-harvest and post-harvest losses. [6-10]. Coniella granati Sacc., one of these fungal pathogens. (sexual stage Schizoparme versoniana) is an important disease factor that threatens the whole world, leading to serious pre-harvest and post-harvest losses. Crown rot disease causes tree decline, blight on branches and post-harvest fruit decay. Presence of this disease has been identified in Brazil, Cyprus, Italy, Spain, Korea, Florida, Israel, Iran, China, North Carolina, Pakistan, Netherlands, Mexico, Greece, Turkey and the United States [11].

It is observed that the disease forms the first symptoms on pomegranate fruit as small, round and hard brown spots, and over time, the size of these spots grows, their color becomes darker, and eventually the whole fruit rots. Necrosis, which begins in the lower part of the root, causes wilting over time, and dieback occurs in young branches. The causal agent, which spends the winter in dead shoots, mummified fruits and pruning places, is transmitted to healthy plants through rain or irrigation water [9, 12-14].

Although cultural and chemical control is proposed against the agent, limited information is available on this subject. It is advised to avoid planting too close together, to perform regular pruning, to keep the number of stems small, since pomegranate plants constantly form new stems and to remove the infected fruits. In addition, the use of resistant varieties as a cultural measure is the best method of control, but the lack of study on the susceptibility/resistance of different genotypes and cultivars of pomegranate plants to the this disease 
prevents an effective control [9]. Chemical control, which is an effective and practical method, is lacking because of limited number of fungicides (thiophanate methyl, tebuconazole and fludioxonil) and studies on new fungicides that will be effective against fruit decay $[9,15$, 16]. In addition, due to the negative effects of fungicides on environment and human health, residues and lastingness problems, the search for alternative combat methods has become mandatory [17].

In recent years, usability of microbial antagonists, which are friendly to the environment and human health, which may be an alternative to chemical control with no residue problem and no risk of lastingness, or the antibiotic, enzyme-like substances produced by them, to prevent plant diseases has been demonstrated by many studies $[18,19]$. Bacteria within these microbial antagonists are used as an effective biological control agent against many fungal and bacterial diseases [20-26]. However, in the literature review, no biological control of bacterial origin against this pathogenic fungus has been encountered.

In this study, 11 bacteria [Bacillus megaterium (TV 3D), Bacillus substilis (TV 6F, TV 17C, CP 1), Bacillus cereus (TV 85D), Paenibacillus polymxa (TV 12E) and Pseudomonas fluorescens (MF 3 and AR 9), BA 7 (Burkholderia cepacia), MF 1 (Pantoea agglomerans) and BAB420 (Bacillus thrungiensis)] were tested in vitro against C. granati, which could be an alternative to the use of synthetic pesticides.

\section{Materials and Methods}

\subsection{Pathogen Fungi and Bioagent Bacteria}

Table 1. Bioagent bacteria, MIS results and isolated from

\begin{tabular}{|c|c|c|c|}
\hline Bacteria & MIS results & Isolated from & References \\
\hline TV 3D & Bacillus megaterium & Rye & {$[27]$} \\
\hline TV 12E & $\begin{array}{c}\text { Paenibacillus } \\
\text { polymyxa }\end{array}$ & Wheat & {$[28]$} \\
\hline AR 9 & $\begin{array}{c}\text { Pseudomonas } \\
\text { fluorescens }\end{array}$ & Soil & {$[29]$} \\
\hline MF 3 & $\begin{array}{c}\text { Pseudomonas } \\
\text { fluorescens }\end{array}$ & Soil & {$[30]$} \\
\hline TV 6F & Bacillus substilis & Wheat & {$[28]$} \\
\hline TV 17C & Bacillus substilis & Raspberry & {$[27]$} \\
\hline TV 85D & Bacillus cereus & Sugar beet & {$[28]$} \\
\hline CP 1 & $\begin{array}{c}\text { Bacillus subtilis } \\
\text { Ricania } \\
\text { simulans }\end{array}$ & {$[31]$} \\
\hline BA 7 & $\begin{array}{c}\text { Burkholderia } \\
\text { cepacia }\end{array}$ & Soil & {$[32]$} \\
\hline MF 1 & $\begin{array}{c}\text { Pantoea } \\
\text { agglomerans }\end{array}$ & Apple & $\begin{array}{c}\text { In this } \\
\text { study }\end{array}$ \\
\hline $\begin{array}{c}\text { BAB } \\
420\end{array}$ & $\begin{array}{c}\text { Bacillus thrungiensis } \\
\text { Ricania }\end{array}$ & $\begin{array}{c}\text { In this } \\
\text { study }\end{array}$ \\
\hline
\end{tabular}

Pathogen fungi was isolated from diseased pomegranate fruit taken from greengrocer in Erzurum/Turkey. Bioagent bacteria effective in our previous biological control studies were used in this study. A total of 11 bacteria isolates were obtained from the Department of Plant Protection, Plant Clinical Laboratory Microorganism Culture Collection, Faculty of Agriculture at Ataturk University, Turkey. The diagnosis according to fatty acid methyl esters result and host information of these bacterial isolates are given in Table 1.

\subsection{Isolation and Identification Fungus}

One more small pieces of tissue taken from diseased and healthy tissue and subjected to surface sterilization with $70 \%$ ethanol for $3 \mathrm{~min}$, and rinsed with sterile distilled water and then dried on sterilized whatman paper. The pieces were placed on Potato Dextrose Agar (PDA) (Merck, Darmstadt, Germany) and petri plates were incubated at $25-27^{\circ} \mathrm{C}$ for 4 days in incubator. Afterwards, fungal hyphae plugs from the fruit tissues were transferred fresh PDA to obtain the pure culture. This fungus is maintained on PDA slant agar in the Department of Plant Protection, Plant Clinical Laboratory Microorganism Culture Collection, Faculty of Agriculture at Ataturk University, Turkey as strain ET 85.

\subsection{Pathogenicity Test of Fungi}

The pathogenicity of isolate ET 85 was tested on pomegranate fruit. The pomegranate fruits were washed under tap water and then surface sterilised with 70\% ethanol, fruits washed twice by dipped in sterilised distilled water and then they were left on sterilized filter paper in laminar cabinet for remove excess water on the surface. Fungi isolate was developed for 4 days on PDA at $27^{\circ} \mathrm{C}$. The mycelial disks taken from the end portions of the pathogen fungi were placed in the wound area on the fuit surface and wound area wrapped with parafilm. Afterwards, the fruits were placed in transparent plastic boxes with damp sterile filter paper and they were stored at room temperature under a photoperiod of 12-h light and 12-h dark. After incubation for 5 days, decay on the fruit surface and fungal mycelial growth were determined as a positive pathogenicity test and re-isolation was done from the symptoms and Koch postulates were completed. Blank disc PDA was used as a negative control. Each treatment was applied to three replicates of 1 fruit in each experiment. The isolates were maintained on a slant agar which compound PDA for further use at $4^{\circ} \mathrm{C}$ in Atatürk University, Agriculture Faculty, Plant Protection Department, Plant Clinic Laboratory.

\subsection{Pathogen Fungus Molecular Identification}

Molecular sequence was carried out to confirm the identify of the pathogen fungus. Genomic DNA was 
extracted from mycelia using the protocol by Moller et al 1992. The rDNA internal transcribed spacer region of pathogen fungus was amplified using primers ITS1-ITS4 [34]. The amplified PCR product sample was sent to the Refgen Co. Ltd., Turkey for sequencing and the resulting sequence was submitted to Genbank.

\subsection{Bioassay}

Petri dishes $(90 \mathrm{~mm})$ containing $20 \mathrm{ml}$ PDA were used in bioassay. Bioagent bacterial isolates were grown on Nutrient Broth (NB) at for $24 \mathrm{~h}$ to obtain fresh culture for in vitro dual culture method. Pathogen fungi isolate was grown for 5 days at $27^{\circ} \mathrm{C}$ on PDA. Bacterial suspensions were individually streaked with a sterile swap on the PDA plates as a circular inner edge of the plate and pathogen fungi was placed in the middle of the petri plates. The plates were wrapped with parafilm, and then were incubated at $27^{\circ} \mathrm{C}$ in incubator until fungal mycelia completely covered the control petri plates. As control, only mycelial disks of pathogenic fungi were placed in the middle of petri plates. Pathogen fungi radial growth was measured in $\mathrm{mm}$. Three replicates of each treatment were made [35].

The percentage inhibition rate of pathogen fungi by bioagent bacterial isolates were calculated by using the formula [34].

$$
\text { Inhibition }(\%)=(\mathrm{C}-\mathrm{T}) \times 100 /(\mathrm{C}-6)
$$

$\mathrm{C}$ : the diameter of the pathogen colony of control group

$\mathrm{T}$ : the diameter of pathogen colony after treatments

6: the diameter of pathogen disk.

\subsection{Statistical Analyses}

All data in the present study were processed by JUMP 5.0.1 and the means were separated by LSMeans Student's tests. The statistical analyses of percentage values in relation to the fruit set were performed using transformed values.

\section{Results}

\subsection{Isolation and Identification Fungus}

Fungal hypha firstly developed in orange pigment in isolation. This orange pigment is from the fruit, not from the fungus. Afterwards, fungal colonies with white aerial mycelia and concentric rings of black pycnidia various sizes were observed when transferred to fresh PDA medium. Hyphae were septate and conidia were hyaline, one-celled, ellipsoid to fusiform (average 10.1-20.2×3.2$4.3 \mu \mathrm{m}$ ). Morphological character of C. granati (ET 85) isolate on PDA and pathogenicity test results were given in Fig 1.
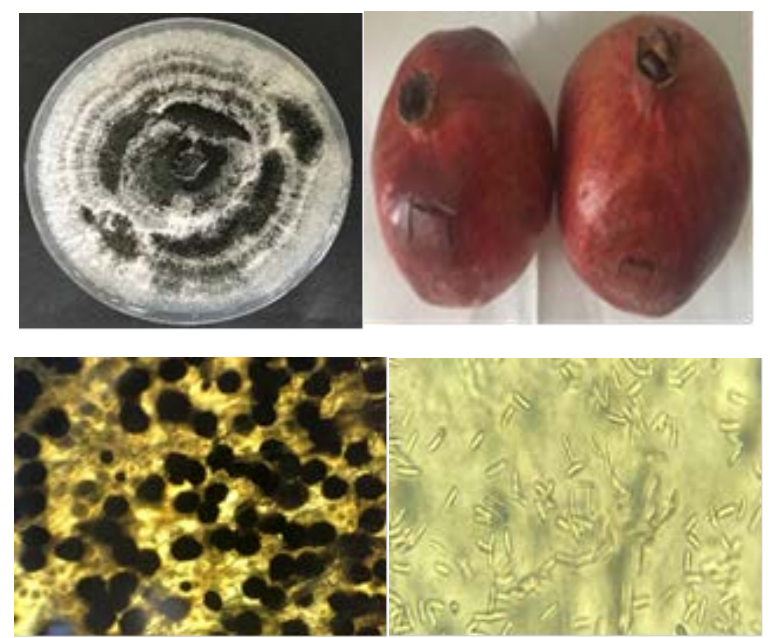

Figure 1. Morphological character and pathogenicity test result of Coniella granati

\subsection{Pathogen Fungus Molecular Identification}

Pathogen fungus sequence was done. All sequence was submitted to Genbank and registered with the 636bp Accesion number MH992151. Pathogen fungi sequence was compared with other ITS sequences by BLASTn analysis and $99 \%$ identity with those of C. granati from pomegranate from South Africa (KT279814), China (HQ166057) and Mexico (KX369239).

\subsection{Bioassay}
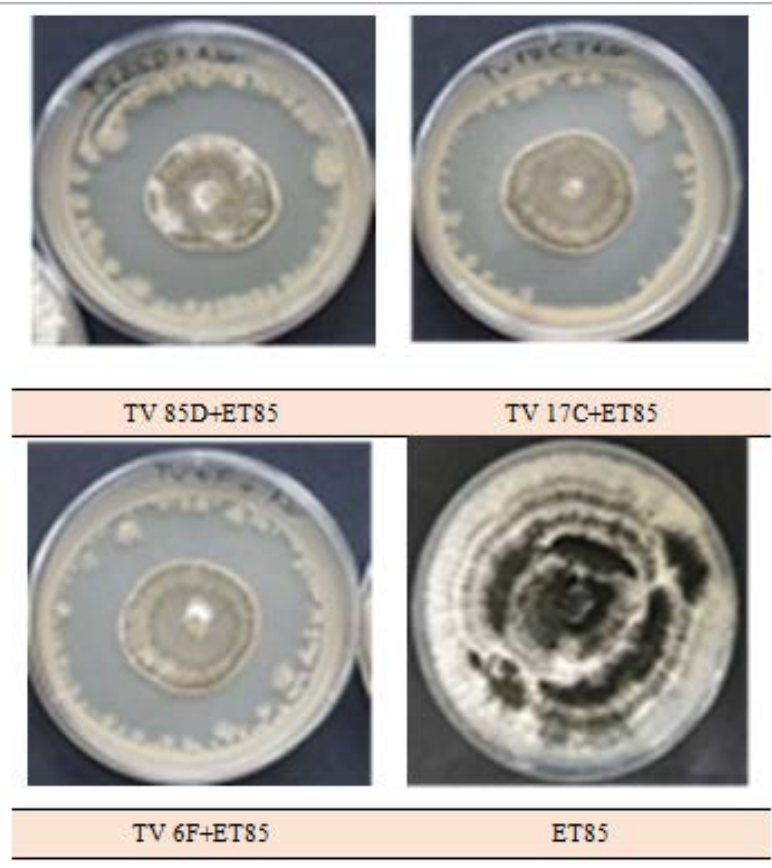

Figure 2. The three most effective bioagent bacteria in the dual culture test

All bacterial isolates showed more or less antifungal activity against the pathogen compared with the control, 
according to the results of biocontrol activity in vitro in this study, The radial growth of the pathogenic fungus ranged from in dual culture. In vitro inhibition test results of the most effective bioagent bacteria isolates were shown in Fig. 2.

In vitro inhibition test results of bioagent bacteria isolates were tested against $C$. granati were shown in Table 2. The percent inhibition rate in the control was statistically different from all other tested bacteria (Table 2). Percentage inhibition rate values were changed between 11.9-66.67\%. The highest percent inhibition rate was observed in TV85D (66.67\%), followed by isolate TV 17C (64.29\%) and TV6F (60.71\%). The lowest percent inhibition rate was observed in BAB 420, AR 9 and TV 3D isolates (11.9\%).

Table 2. The percentage inhibition rate of Coniella granati in dual culture

\begin{tabular}{|l|c|c|}
\hline Bacteria & \multicolumn{2}{|c|}{ PIRG* } \\
\hline TV 85D & 66.67 & A \\
\hline TV 17C & 64.29 & A \\
\hline TV 6F & 60.71 & B \\
\hline CP 1 & 46.43 & C \\
\hline MF 3 & 26.19 & D \\
\hline MF 1 & 23.81 & D \\
\hline BA 7 & 19.64 & E \\
\hline TV 12E & 17.26 & E \\
\hline BAB 420 & 11.90 & F \\
\hline AR 9 & 11.90 & F \\
\hline TV 3D & 11.90 & F \\
\hline Control & 0.00 & G \\
\hline LSD & & 3.17 \\
\hline CV & & 0.06 \\
\hline
\end{tabular}

*There is no statistically significant difference between values expressed in the same column with similar letters $(\mathrm{P}<0.01)$.

\section{Discussion}

C. granati is an important fungal agent that causes preand post-harvest fruit decay and poses a new threat to the rapidly growing pomegranate industry in many parts of the World [11]. Post-harvest disease management for pomegranate fruit remains an important problem [37]. In the control against disease, cultural measures and chemical control are recommended. However, while cultural measures provide limited protection, limited information on chemical control and its disadvantages necessitates the use of alternative control methods [8]. For this reason, the biological control method, which is among alternative combat methods and friendly to the environment and human health with no risk of lastingness and residue problem, is an effective and important control method [9].
The species belonging to the genera Bacillus, Pseudomonas and Burkholderia have been used by different researchers as a bioagent in biological control [10, 19, 31, 38]. Since Bacillus group bacteria, among these bacteria, have a number of advantages over other bacteria (such as endospore formation, wide spectrum activity of their antibiotics), it is emphasized that they have the potential to be used against pathogens [39]. It has been noted that bacteria from the genus Pseudomonas lives in the soil, encourage plant growth and bioremediation, and that due to their easy colonization, competitive ability and wide antimicrobial spectra they have an important place among bioagents [40].

In this study, 11 bacterial bioagents belonging to the genera Bacillus, Paenibacillus, Pseudomonas and Burkholeria, which were previously used as biological warfare agents in different studies were used. All of the bacterial bioagents tested in vitro against $C$. granati isolate were more or less effective on the development of the pathogen, except for the control. In this study, the most promising results were obtained, and $B$. cereus (TV 85D) and B. substilis (TV 17C) species were successfully used in the control against pests and diseases, which has also been recorded by different researchers [26,31,41-43].

Tozlu et al. (2016), tested two isolates of B. substilis in vitro and in vivo against Sclerotinia sclerotiorum and determined that TV 17C isolates were highly effective in preventing the disease. Again, Tozlu et al. (2017) and Tozlu et al. (2018c) noted that the same isolate yielded effective results against Penicillium digitatum and Alternaria alternata, respectively. These results indicate that TV $17 \mathrm{C}$ is also effective on other pathogens. In addition, Tozlu et al. (2018c) showed that this isolate inhibits the development of the pathogen by degrading the chitin found in the cell wall of the pathogen with glucanase and protease enzymes. In this study, the fact that TV $17 \mathrm{C}$ at $64.29 \%$ in vitro conditions prevented the development of C. granati showed that this bacterial isolate can be used as an important biological warfare agent.

Tekiner et al. (2018) tested the TV 85D bacterial isolate against $3 \mathrm{~B}$. cinerea and $1 \mathrm{~A}$. alternata in vitro and found that it prevented the development of A. alternat at $64.29 \%$ and B. cinerea at $64.29-80.36 \%$.

Jiang et al. (2017) revealed that B. cereus AR156 isolate promotes plant growth, induces systemic resistance mechanism and protects tomato plants against bacterial wilt caused by Ralstonia solanacearum and root-knot nematode Meloidogyne incognita. In this study also, TV 85D (B. cereus), the most effective isolate, has been shown to inhibit the development of pathogenic fungi in vitro conditions as well.

In a study conducted by Kotan et al. (2014), it was determined that TV 85D, TV 17C and TV $6 \mathrm{~F}$ bacterial isolates could be used both in agriculture as biopesticides and bio-fertilizer. In another study, it was found that, the 
application of TV 17C bacteria in the cauliflower plant increased plant growth parameters such as wet and dry shoot weight, root diameter and root length, wet and dry root weight, plant height, leaf surface area and chlorophyll content [27]. Thus, it was noted that this bacteriological isolate has both regulatory effects on plant development and prevents from diseases.

Al-Hussini et al. (2018) tested that B.cereus (D1/17) used against Pythium aphanidermatum (damping-off on tomato) and they observed that according to control $27 \%$ prevent the disease. Also they revealed that this bioagent bacteria is an plant growth promoting bacteria, induced the maximum shoot length and seedling vigor.

Awan and Shoaib (2019) explored that in vivo biocontrol efficacy of $B$. subtilis alone and in combination with plant nutrients [NPK, Zn (1X \& 2X), Mg and B] against early blight disease of tomato (A. solani). They revealed that foliar application of $B$. subtilis alone and in combination with the plant nutrients managed early blight disease significantly by $67-83 \%$, while improved plant growth attributes by $20-77 \%$. B. subtilis and plant nutrients helped the tomato plant to fight off the plant hacker by up-regulating the production of total phenolic contents and defensive enzymes. This and other studies shows that Bacillus sp. effectively managed the diseases.

\section{Conclusions}

In conclusion, this study is important in terms of identification of bacteria that can be used as a bio-agent against $C$. granati, which causes significant yield losses in pomegranate. In this study, it was determined that bacterial isolates belonging to $B$. cereus and $B$. subtilis were effective on the development of the disease causing agent in vitro conditions. It is likely that this effect may vary in storage conditions with different values of temperature and humidity. It is of great importance to conduct studies in order to determine the effectiveness of the formulations of these two bacteria species, which are effective against fruit decay, together or separately in the storage conditions.

\section{REFERENCES}

[1] Leontopoulos, S, Skenderidis, P, Kalorizou, H, Petrotos K (2017). Bioactivity potential of polyphenolic compounds in human health and their effectiveness against various food borne and plant pathogens. A review. International Journal of Food and Biosystems Engineering 7(1): 1-19.

[2] Bar-Ya'akov I, Tian L, Amir R, Holland D (2019). Primary metabolites, anthocyanins, and hydrolyzable tannins in the pomegranate fruit. Frontiers Plant Science, 10, 620, doi: 10.3389/fpls.2019.00620.
[3] Gündoğdu M, Yılmaz H (2013). Bazı standart nar (Punica granatum L.) çeşitleri ve genotiplerine ait meyvelerin C vitamini, şeker ve besin elementleri içeriklerinin belirlenmesi. Yüzüncü Yıl Üniversitesi Tarım Bilimleri Dergisi, 23: 242-248.

[4] Agrios GN (1997). Plant Pathology, Fourth Edition, London, Academic Press.

[5] Gustavsson J, Cederberg C, Sonesson U, van Otterdijk R, Meybeck A. (2011). Global food losses and food waste: extent, causes and prevention. Rome: Food and Agriculture Organisation of the United Nations (FAO), 29.

[6] Sherkar BV, Utikar PG (1982). Beltraniella humicola a new fruit spotting fungus on pomogranate. Indian Journal of Mycology and Plant Pathology, 12(1):50.

[7] Labuda R, Hudec K, Pieckova E, Mezey J, Bohovic R, Mateova S, Lucas SS (2004). Penicillium implicatum causes a destructive rot of pomogranate fruits. Mycopathologie, 157: 217-223.

[8] Pala H, Y1lmaz C, Özgüven AI, Tatlı A (2006). Important disease of pomogranate fruit and control possibilities in Turkey. 1st Int. Sym. on Pomogranate and Minor Mediterranean Fruits, 16-19 Ekim 2006, 4, Adana.

[9] Thomidis T (2015). Pathogenicity and characterization of Pilidiella granati causing pomegranate diseases in Greece. European Journal of Plant Patholology, 141, 45-50.

[10] Teksur PK (2015). Alternative technologies to control postharvest diseases of pomegranate. Stewart Postharvest Rev. 11, 1-7.

[11] Yang X, Hameed U, Zhang A, Zang H, Gu C, Chen Y, Xu $Y$ (2017). Development of a nested-PCR assay for the rapid detection of Pilidiella granati in pomegranate fruit. Scientific Reports, DOI: 10.1038/srep40954.

[12] Mirabolfathy M, Groenewald JZ, Crous PW (2012). First report of Pilidiella granati causing dieback and fruit rot of pomegranate (Punica granatum) in Iran. Plant Disease, 96: 461.

[13] Çeliker NM, Uysal A, Çetinel B (2012). Crown rot on pomegranate caused by Coniella granati in Turkey. Australasian Plant Disease Notes, 7: 161-162.

[14] Uysal A, Kurt S, Soylu ME, Kara M, Soylu S (2018). Morphology, Pathogenicity and Management of Coniella Fruit Rot (Coniella granati) on Pomegranate. Turkish Journal of Agriculture - Food Science and Technology, 6(4): 471-478.

[15] Adaskaveg J, Förster H, (2002). New detection and management practices for brown rot of peach in California. Acta Horticulture, 592:637-643.

[16] Sharma RL (2005) Management of brown rot (Monilinia laxa) in peaches in warmer areas. Acta Horticult, 696: 359-362.

[17] Cook RJ, Baker KF (1983). Why biology control? In: The Nature and Practice of Biology Control of Plant Pathogens. St. Paul, APS: 1-28.

[18] Smilanick JL., Mansour MF., Margosan DA., Gabler FM, Goodwine WR (2005). Influence of $\mathrm{pH}$ and NaHCO3 on effectiveness of imazalil to inhibit germination of 
Penicillium digitatum and to control postharvest green mold on citrus fruit. Plant Disease, 89: 640-648.

[19] Sharma RR, Singh D, Singh R (2009). Biological control of postharvest diseases of fruits and vegetables by microbial antagonists: a review. Biological Control, 50: 205-221.

[20] Sharma S, Sharma J (2008). A study of stress and cope-up strategies of service sector employees. Indian Management Studies Journal, 12:19-35.

[21] Kotan R, Dikbaş N, Bostan H (2009). Biological control of postharvest disease caused by Aspergillus flavus on stored lemon fruits. African Journal of Biotechnology, 8: 209-214.

[22] Matar SM, EI-Kazzar SA, Wagih EE, EI-Diwany AI, Moustafa HE, Abo-Zaid GA, Abd-EIsalam Hafez EE (2009). Antagonistic and inhibitory effect of Bacillus subtilis against certain plant pathogenic fungi. International Biotechnology, 8:53-61.

[23] Elshafie HS, Camele I, Racioppi R, Scrano L, Iacobellis NS, Bufo SA (2012). In vitro antifungal activity of Burkholderia gladioli pv. agaricicola against some phytopathogenic fungi. International Journal of Molecular Science, 13: 16291-16302.

[24] Ketabchi S., Taghipour M.A., Sharzei A. (2012). Identification of lime fruit surface colonizing bacteria antagonistic against the green mold and comparison of biological control with heat treatment and chemical control. Asian Journal of Experimental Biological Sciences, 3: 287-292.

[25] Kotan R, Mohammadi P, Karagöz K, Dadaşoğlu F, Güneş A, Tozlu E (2014). Determination of broad spectrum bacterial strains which can be used as bio-pesticides and bio-fertilizers in agriculture. In: Vth Turkey Plant Protection Congress, Feb 3-5, 2014, Antalya, Turkey: 313.

[26] Tozlu E, Tekiner N, Kotan R (2018a). Screening of Trichoderma harzianum Rifai (1969) isolates of domestic plant origin against different fungal plant pathogens for use as biopesticide. Fresenius Environmental Bulletin, 27(6):4232-4238.

[27] Ekinci M, Turan M, Yıldırım E, Güneş A, Kotan R, Dursun A (2014). Effect of plant growth promoting rhizobacteria on growth, nutrient, organic acid, amino acid and hormone content of cauliflower (Brassica oleracea L. var. botrytis) transplants. Acta Scientiarum Polonorum. Hortorum Cultus, 13(6):71-85.

[28] Erman M, Kotan R, Çakmakçı R, Çı̆̆ F, Karagöz K, Sezen $M$ (2010). Effect of nitrogen fixing and phosphate-solubilizing rhizobacteria isolated from Van Lake Basin on the growth and quality properties in wheat and sugar beet. Turkey IV. Organic Farming Symposium, 28 June-1 July, Erzurum, Turkey, pp 325-9.

[29] Varmazyari A (2015). The study of the effect of plant growth promoting bactria on tea development, production, some quality parameters and enzyme activities. Atatürk University, Phd thesis, Turkey.

[30] Güneş A, Karagöz K, Turan M, Kotan R, Yıldırım E, Çakmakçı R and Şahin F (2015). Fertilizer effiency of some plant growth promoting rhizobacteria for plant growth. Research Journal of Soil Biology 7(2): 28-45.
[31] Tozlu E, Tekiner N, Tozlu G, Kotan R, Calmaşur Ö, Göktürk T, Dadaşoğlu F (2018b). Icerya purchasi Maskell, 1878 (Hemiptera: Margarodidae)'nin Entomopatojen Fungus ve Bakterilerle Biyolojik Mücadelesinin Araştırılması. Conference: III. Türkiye Orman Entomolojisi ve Patolojisi Sempozyumu, 10-12 May1s 2018, Artvin, Türkiye.

[32] Güneş A, Turan, M, Güllüce M, Şahin F, Karaman MR. (2013). Farklı Bakteri Uygulamalarının Kaya Fosfatının Çözünürlüğü Üzerine Etkisi. Soil-Water Journal, 2(1): 53-61.

[33] Moller EM, Bahnweg G, Sandermann H, Geiger HH (1992). A simple and efficient protocol for isolation of high molecular weight DNA from filamentous fungi, fruit bodies and infected plant tissues. Nucleic Acids Res.; 20(22):6115-6116.

[34] White TJ, Bruns T, Lee S, Taylor J (1990). Amplification and direct sequencing of fungal ribosomal RNA genes for phylogenetics. In: PCR Protocols: a guide to methods and applications. (Innis MA, Gelfand DH, Sninsky JJ, White TJ, eds). Academic Press, New York, USA: 315-322.

[35] Tozlu E, Tekiner N, Kotan R and Örtücü S (2018c). Investigation on the biological control of Alternaria alternata. Indian Journal of Agricultural Sciences 88(8):1241-1247.

[36] Mari M., Iori R., Leoni O., Marchi A. (1993): In vitro activitiy of glucosinolate-derived isothiocyanates against postharvest fruit pathogens. Annals of Applied Biology, 123: 155-164.

[37] Munhuweyia K, Lennox CL, Meitz-Hopkins JC, Caleb OJ, Sigged GO, Opara UL (2017). Investigating the effects of crab shell chitosan on fungal mycelialgrowth and postharvest quality attributes of pomegranate whole fruitand arils. Scientia Horticulturae 220:78-89.

[38] Panebianco S, Vitale A, Polizzi G, Scala F, Cirvilleri G (2015). Enhanced control of postharvest citrus fruit decay by means of the combined use of compatible biocontrol agents. Biological Control, 84: 19-27.

[39] Abdalla SA, Algam SAA, Ibrahim EA, Naim AM (2014). In vitro screening of Bacillus isolates for biological control of early blight disease of tomato in Shambat soil. World Journal of Agricultural Research, 2: 47-50.

[40] Gao, G, Yin D, Chen, S, Xia, F, Yang, J, Li Q, Wang W (2012). Effect of Biocontrol Agent Pseudomonas fluorescens 2P24 on soil fungal community in cucumber rhizosphere using T-RFLP and DGGE. Plos One, 7(2).

[41] Quan CS, Zheng W, Liu Q, Otha Y, Fan SD (2006). Isolation and characterization of a novel Burkholderia cepacia with strong antifungal activity against Rhizoctonia solani. Applied Microbial and Cell Physiology, 72:1276-1284.

[42] Nagorska K, Bikowski M, Obuchowskji M (2007). Multicellular behaviour and production of a wide variety of toxic substances support usage of Bacillus subtilis as a powerful biocontrol agent. Acta Biochimica Polonica, 54, 495-508.

[43] Ji XL, Lu GB, Gai YP, Zheng CC, Mu ZM (2008). Biological control against bacterial wilt and colonization 
of mulberry by an endophytic Bacillus subtilis strain. FEMS Microbiol Ecology, 65:565-573.

[44] Tozlu E, Mohammadi P, Kotan M, Nadaroglu H, Kotan R (2016). Biological control of Sclerotinia sclerotiorum (Lib.) de Bary, the causal agent of white mould disease in red cabbage, by some bacteria. Plant Protection Sciences, 52(3).

[45] Mohammadi P, Tozlu E, Kotan R, Kotan M. (2017). Potential of some bacteria for biological control of postharvest citrus green mould caused by Penicillium digitatum. Plant Protection Science, 53(3):134-143.

[46] Tekiner N, Tozlu E, Kotan R, Dadasoğlu F (2018). Biological control of Botrytis cinerea and Alternaria alternata with bioagent bacteria and fungi under in vitro conditions. Conference: 2nd International professional and technical sciences congress (UMTEB) May 10-13, 2018 Batumi / Georgia.

[47] Jiang C, Chen Y, Yan F, Fan Z, Guo J (2017). Whole-genome sequence of Bacillus cereus AR156, a potential biocontrol agent with high soilborne disease biocontrol efficacy and plant growth promotion. American Society for microbiology, https://doi.org/10.1128/.

[48] Al-Hussini SH, Al-Rawahi YA, Al-Marhoon AA, Al-Abri AS, Issa H. Al-Mahmooli HI, Al-Sadi MA, Velazhahan R (2019). Biological control of damping-off of tomato caused by Pythium aphanidermatum by using native antagonistic rhizobacteria isolated from Omani soil. Journal of Plant Pathology, 101(2):315-322.

[49] Awan AZ, Shoaib A (2019). Combating early blight infection by employing Bacillus subtilis in combination with plant fertilizers. Current Plant Biology, 20(12), 100125, https://doi.org/10.1016/j.cpb.2019.100125. 